\title{
RESENHAS
}

\section{PEDAGOGIA COMO CIÊNCIA DA EDUCAÇÃO}

Maria Amélia Santoro Franco

Campinas: Papirus, 2003, I44p.

O livro é uma contribuição diferenciada entre os estudos epistemológicos da Pedagogia por tratar-se de uma pesquisa de base, de fôlego teórico. $\bigcirc$ objetivo sistematicamente reafirmado ao longo do texto é a busca de fundamentos para compreender a cientificidade da pedagogia no seu caminho para se constituir ciência em educação. Seu foco não está na visão positivista de ciência, mas na relação entre práxis e epistemologia, uma vez que a especificidade epistemológica da pedagogia encontra seu suporte, na prática educativa, práxis considerada em uma dimensão de intencionalidade. Precisamente porque a pedagogia viabiliza uma práxis educativa, a práxis pedagógica será o exercício do fazer científico da pedagogia sobre a prática educativa.

A obra, em três capítulos, mostra no primeiro os caminhos históricos da Pedagogia, no segundo, apresenta as bases teóricas e epistemológicas da pedagogia como ciência da educação e, no terceiro, propõe alternativas da formação profissional do pedagogo como cientista educacional.

No capítulo I, a autora discute o percurso histórico da Pedagogia tratada ora como arte, ora como ciência e até como ciência da arte educativa, mostrando as dificuldades da discussão de sua epistemologia. Na sistematização desse percurso, são caracterizadas três grandes concepções: a Pedagogia filosófica, a Pedagogia técnico-científica e a Pedagogia crítico-emancipatória. Na Pedagogia filosófica, a ação pedagó- gica é voltada para a educação do homem integral, em todas as suas dimensões e assume ora caráter normativo, ora compreensivo, envolvendo diferentes influências teóricas como o humanismo clássico, o iluminismo, o romantismo e o idealismo. A pedagogia técnico-científica, ancorada no método experimental de cunho racional empirista, postula a normatização e a prescrição para a prática educativa voltada para fins de inserção social dos educandos. Com suporte na Filosofia, Psicologia e Sociologia, essa orientação inclui desde Comênio e Herbart a Durkheim e Dewey, mas também as concepções sociocríticas sustentadas na teoria marxista. A Pedagogia crítico-emancipatória propõe uma ação pedagógica para formar indivíduos na e pela práxis, com forte sentido de transformação da realidade socioistórica, que toma o conhecimento em sua ligação com a vida social. Teoricamente associa-se à dialética, à filosofia da práxis, incorporando elementos da teoria crítica da Escola de Frankfurt.

No capítulo 2, "A Pedagogia como ciência da educação", o leitor se envolverá com a determinação de Franco de enfatizar sua opção por uma "ciência pedagógica ou pedagogia como ciência", concebida como um instrumento político e de emancipação. A autora apresenta seu entendimento sobre as bases dessa ciência, seu objeto, as relações entre práxis educativa e práxis pedagógica. Assinala o desprezo à Pedagogia, demonstrado nos planos nacionais, estaduais e municipais de educação dos respectivos governos, principalmente na década neoliberal dos anos 90 , bem como nas práticas institucionais, que relegam a Pedagogia a aspectos meramente organizativos, o que tem provocado a perda de "sentido", de "identidade", da "razão de ser" da Pedagogia. Segundo a autora, 
outras ciências como a Psicologia, a Sociologia têm galgado espaços educacionais amplos que deveriam estar ocupados pela Pedagogia. Contudo, nenhuma delas alcançou o posto de ciência da educação que define a especificidade do estudo do fenômeno educativo, sem relegar a importância das ciências auxiliares na educação, entre outras, a Psicologia e a Sociologia. Neste capítulo nuclear de seu livro, Franco afirma que a Pedagogia como ciência deve ter por finalidade "o esclarecimento reflexivo e transformador da práxis educativa, discutindo as mediações possíveis entre teoria e práxis". Cabe-lhe o papel de ser uma "explícita mediadora da práxis educacional", que conduz o sujeito à humanização, à emancipação, a apreender e reconstruir a cultura, conditio sine qua non da cidadania.

Como ciência da educação a Pedagogia precisa passar da racionalidade técnica à racionalidade prática, reflexiva, formativa e emancipatória. A formação de pedagogo deve enfatizar o aspecto crítico-reflexivo, que compreenda a complexa pluralidade do âmbito educacional, a necessidade de mediar um processo de aprendizagem voltado para a formação integral de um sujeito de pensamento fragmentado, acrítico, alienado das questões políticas e socioculturais. Está claro que essa tarefa extrapola os muros escolares.

Finalmente, no capítulo 3, a autora formula sua proposta de formação de um pedagogo cientista educacional, e argumenta que, para possibilitar a sobrevivência profissional e valorização da prática do magistério, urgem "re-interpretações de conceitos basilares, ampliando o espaço científico da Pedagogia". Conclui, definindo o pedagogo como o investigador educacional por excelência, com características de profissional crítico e reflexivo, uma vez que a Pedagogia é uma ciência que visa o estudo e a compreensão da práxis educativa em suas intencionalidades. Para isso, a investigação parte da práxis, como ação coletiva, pois as teorias educacionais não determinam prá- ticas educativas, antes, convivem com elas em múltiplas articulações.

O livro apresenta-se, assim, como valioso instrumento de compreensão da Pedagogia como ciência da educação e também como orientação para a formulação do currículo de formação de pedagogos especialistas e professores e para os fundamentos teóricos da pesquisa pedagógica. São contribuições oportunas, significativas e legítimas; nenhuma delas oportunista, mesquinha ou corporativista, como mostram as perguntas da autora: "Se não é a Pedagogia como ciência da educação a condutora e operacionadora desse movimento de formação de professores reflexivos, qual outra ciência pode assumir esse papel? Qual outra alternativa, em relação à formação de professores se não a racionalidade crítico-reflexiva? É possível transformar essas propostas em projeto educacional? Se não os pedagogos, quem deve assumir a condução deste projeto?" (p. I24).

Para além do interesse teórico e investigativo, o livro de Maria Amélia Santoro Franco contribui para esclarecer aspectos do debate que se tem travado na área educacional a respeito da formação de educadores, reafirmando a tradição teórica em que a Pedagogia, como ciência da educação, formula a partir da práxis educativa os elementos científicos e técnicos da formação humana, constituindo referência para todas as práticas educativas, entre elas o trabalho docente. Ou seja, a docência fundamenta-se na Pedagogia e não o inverso.

José Carlos Libâneo

Programa de Pós-Graduação em Educação da Universidade Católica de Goiás libaneojc@uol.com.br

Lelis Dias Parreira

Mestrando do Programa de Pós-Graduação em Educação da Universidade Católica de Goiás lelisdp@universiabrasil.net 